\title{
Menjawab Tantangan Pengasuhan Ibu Bekerja: Validasi Modul "Smart Parenting" untuk Meningkatkan Parental Self-Efficacy
}

\author{
Fitri Hayati ${ }^{1}$ E Arum Febriani ${ }^{2}$ \\ Fakultas Psikologi Universitas Gadjah Mada
}

\begin{abstract}
This study aimed to validate "Smart Parenting" a training module to increase feeling of competence in carrying out the duties as parent, or Parental Self-Efficacy (PSE) of working mothers with toddler. The research was conducted using a quasi-experimental design in a model of untreated control group design with dependent pretest, posttest, and follow up among 12 participants. Six participants were in treatment group, and the other six were in control group. "Smart Parenting" was arranged based on Work-Family Balance and Domain Specific Parenting for Toddler. The maternal self-efficacy was measured using the short version of Self-Efficacy for Parenting Tasks Index-Toddler Scale. The statistical analysis using Mann Whitney Test showed that there was a difference $(p<0.05)$ in mother's PSE between experimental group and control group. This research concluded that the "Smart Parenting" training program is effective for the purpose of increasing PSE for working mothers with toddlers.
\end{abstract}

Keywords : parental self-efficacy; parenting program; working mothers

\begin{abstract}
Abstrak. Penelitian ini bertujuan untuk memvalidasi modul pelatihan "Smart Parenting" untuk meningkatkan perasaan kompetensi ibu bekerja yang memiliki toddler dalam melaksanakan tugas mereka sebagai orangtua, atau Parental Self-Efficacy (PSE). Penelitian ini menggunakan desain kuasi-eksperimen dengan model the untreated control group design with dependent pretest, posttest, and follow up pada 12 partisipan, enam partisipan dalam kelom pok perlakuan, dan enam partisipan dalam kelompok kontrol. Modul "Smart Parenting" disusun berdasarkan Work-Family Balance dan Domain Specific Parenting for Toddler. Pengukuran efikasi ibu merujuk pada versi singkat dari SEPTI-TS (Self-Efficacy for Parenting Tasks Index-Toddler Scale). Analisis statistik menggunakan Uji Mann Whitney menunjukkan bahwa ada perbedaan PSE yang signifikan $(p<0,05)$ antara kelompok eksperimen dan kelompok kontrol. Penelitian ini menunjukkan bahwa program pelatihan "Smart Parenting" efektif untuk meningkatkan PSE ibu bekerja yang memiliki toddler.
\end{abstract}

Kata kunci : efikasi diri pengasuhan; ibu bekerja; program pelatihan pengasuhan

Dalam konteks keluarga Indonesia, khususnya Jawa, salah satu sifat perempuan yang baik yang dijelaskan dalam Serat Yadyasusila adalah gemati yaitu menunaikan kewajiban sebagai istri dengan baik, meliputi merawat rumah

\footnotetext{
1 Korespondensi mengenai isi artikel ini dapat dilakukan melalui amathonte_2012@yahoo.com

2 atau melalui arum_febriani@ugm.ac.id

tangga, mengatur keuangan, dan mendidik anak (Hariwijaya dalam Roqib, 2007). Oleh karena itu, ibu memiliki tanggung jawab terkait dengan urusan domestik rumah tangga dan anak-anak (Khotimah, 2009). Hal ini juga berlaku 
bagi ibu yang bekerja. Selain harus bekerja profesional di luar rumah, sebagai ibu rumah tangga ibu juga memiliki kewajiban menyelenggarakan dan mengatur rumah (Nafisah, 2008).

Peran ganda yang ibu jalankan seringkali membawa dilema tersendiri yang membuat ibu merasa kurang yakin dengan pengasuhan yang dijalankannya, terutama ketika anak masih kecil (toddler/anak usia 2-3 tahun). Ibu rentan merasa sedih, merasa bersalah, merasa tidak maksimal sebagai ibu karena tidak bisa mendampingi proses tumbuh kembang anak secara optimal di masa golden age, sebagaimana yang diungkapkan oleh Mia (nama samaran) dan Tiwi (nama samaran). Perasaan bersalah ibu ini lebih besar daripada perasaan bersalah ayah (Borelli, Nelson, River, Birken, \& Moss-Racusin, 2016). Ibu yang bekerja juga membawa pengalaman dari tempat kerja ke dalam rumah (Crouter \& McHale, 2005) seperti yang diungkapkan Hana (nama samaran) dan Tiwi. Keduanya mengungkapkan bahwa mereka masih membawa permasalahan di kantor ke dalam rumah sehingga memengaruhi pengasuhan.

Praktik pengasuhan yang dilakukan orangtua meliputi pemahaman dan responsitivitas orangtua. Pemahaman orang tua terhadap kebutuhan dan kemampuan anak dalam setiap tahap perkembangan membuat orangtua dapat merespon anak secara empatik serta menyediakan stimulasi yang memadai untuk mendukung tumbuh kembang anak (Levins \& Munsch, 2011). Praktik pengasuhan orang tua salah satunya dipengaruhi oleh parenting cognition (Smith, 2017). Parenting cognition adalah apa yang dipikirkan orang tua tentang anak-anak mereka dan bagaimana mereka memikirkan cara membesarkan anak-anak tersebut (Holden, 2015). Salah satu konstruk yang membangun parenting cognition adalah self-perception dan salah satu jenis selfperception tersebut adalah feeling of self efficacy (Holden, 2015).

$$
\text { Parental self efficacy (PSE) }
$$
merupakan turunan dari konsep self efficacy yang dikemukakan oleh Albert Bandura (Sansom, 2010). PSE adalah estimasi penilaian diri sendiri terhadap kemampuan menjalankan peran sebagai orang tua untuk memberikan pengaruh positif ke dalam tingkah laku dan perkembangan anak mereka (Coleman \& Karraker, 2003). Self-efficacy ini merupakan kunci perubahan tingkah laku individu dalam sistem Bandura (Alwisol, 2009). Oleh karena itu parental self-efficacy menentukan praktik pengasuhan yang dijalankan orang tua.

Dalam studi terdahulu, terbukti bahwa PSE berpengaruh terhadap pengasuhan (Wittkowski, Garrett, Calam, dan Weisberg, 2017; Coleman dan Karraker, 1998), menentukan parental warmth dan parental control (Izzo, Weiss, Shanahan, \& Rodriguez-Brown, 2000), memengaruhi proses pertumbuhan dan perkembangan anak, penyesuaian anak (Jones \& Prinz, 2005), perilaku agresif anak (Rachmawati \& Hastuti, 2017), serta meningkatkan aktivitas fisik anak dan mengurangi screen time pada anak (Huilan, Wen, dan Chris, 2015) .

PSE sendiri dipengaruhi oleh banyak faktor. Dari studi terdahulu, faktor-faktor tersebut adalah persepsi orangtua terhadap anak (Coleman \& Karraker, 2000); pengalaman orangtua (Coleman \& Karraker, 2000; Tom czewski, 2009); usia anak (Coleman \& Karraker 2000); pendapatan keluarga (Coleman \& Karraker, 2000; Yu, 2011); tingkat pendidikan orangtua (Coleman \& Karraker, 2000); pengetahuan orangtua (Tomczewski, 2009); dukungan pasangan, keluarga, teman dan komunitas ( $\mathrm{Yu}$, 2011); keterlibatan orangtua (Dewi \& 
Indrasari, 2017); dan fatigue (kelelahan yang sangat dan terus-menerus) serta dukungan informasional (pemberian nasihat, pengarahan dan masukan) (Ningrum, 2016).

Dengan peran ganda yang dijalankan ibu bekerja, ibu membutuhkan keseimbangan peran dalam keluarga maupun pekerjaannya. Keseimbangan kerja-keluarga ibu mengalami fase terendah ketika berada pada tahap anak terkecil berusia prasekolah dan tahap remaja (Wepfer, Brauchli, Jenny, Hämmig, dan Bauer (2015). Keseimbangan kerja-keluarga adalah pencapaian ekspektasi terkait dengan peran yang dinegosiasikan dan dibagikan antara individu dan mitra perannya dalam domain kerja dan keluarga (Grzywacz dan Carlson, 2007). Dalam perannya di dalam keluarga, tercapainya harapan ibu ini menunjukkan tingkat keyakinan pengasuhan yang baik.

Dalam rangka memberikan dukungan informasional dan menstimulasi terbentuknya keseimbangan kerja-keluarga untuk meningkatkan PSE ibu bekerja dengan anak toddler maka peneliti menyusun sebuah modul pelatihan "Smart Parenting". Bentuk pengembangan PSE yang tepat adalah melalui training (Polivanova, Vopilova, \& Nisskaya, 2016). Oleh karena itu modul ini dikemas dalam bentuk training yang menggunakan sumber-sumber PSE yang disebutkan oleh Bandura (1997), yaitu enactive mastery experiences, vicarious experiences, verbal persuasion, dan psychological and affective states. Penyampaian modul menggunakan metode experiential learning. Metode ini menekankan pada pengalaman individu dan juga kemampuannya dalam merefleksikan pengalamannya untuk membentuk pengetahuan. Menurut Kolb (2015), metode ini dapat membantu mengatasi kesulitan belajar karena berasal dari pengalaman-pengalaman yang dialami. Hipotesis dalam penelitian ini adalah modul pelatihan "Smart Parenting" bisa meningkatkan Parental Self Efficacy ibu bekerja yang memiliki anak toddler.

\section{Metode}

Partisipan penelitian

Pelaksanaan penelitian dilakukan di Bantul, Kota Yogyakarta dan Sleman. Partisipan penelitian ini pada awalnya berjumlah 17 orang, namun hanya 12 partisipan (6 orang menjadi kelompok kontrol dan 6 orang menjadi eksperimen) yang dimasukkan dalam analisis statistic, karena lima orang partisipan merupakan outlier. Teknik sampling yang digunakan adalah purposive sampling dengan kriteria inklusi sebagai berikut: (1) ibu bekerja penuh waktu minimal 40 jam/minggu; (2) memiliki anak berusia 2-3 tahun yang tinggal serumah; (3) memiliki suami yang tinggal serumah; (4) bersedia menjadi partisipan dengan mengikuti program pelatihan selama 1 pekan dan menandatangani informed consent. Dari data demografi diketahui usia partisipan berada pada rentang 26-35 tahun, dengan tingkat pendidikan D3 - S2.

\section{Instrumen penelitian}

Penelitian ini menggunakan 4 instrumen. Kuesioner demografi. Informasi yang diungkap dalam kuesioner demografi adalahdata personal partisipan seperti usia dan jumlah anak.

Modul Pelatihan "Smart Parenting". Modul ini disusun berdasarkan dimensi keseimbangan kerja-keluarga (Greenhaus, Collins \& Shaw, 2003) yaitu peningkatan keseimbangan waktu dan keterlibatan, serta domain PSE untuk toddler (Van Rijen, Gasanova, Boonstra \& Huijding, 2014) 
yaitu nurturance, playing, routine dan discipline. Modul terdiri dari 3 bagian, yaitu panduan training, buku materi untuk peserta serta buku tugas untuk peserta. Pelatihan sendiri terdiri dari empat sesi, sesi pertama mengenai peran orangtua bagi anak, sesi kedua mengenai waktu berkualitas dan keterlibatan orangtua pada dunia anak, sesi ketiga mengenai materi pengasuhan anak untuk anak toddler, dan sesi keempat (dilaksanakan sepekan setelah sesi 1, 2,dan 3) merupakan sesi refleksi dan sesi sharing. Jeda 1 pekan merupakan sesi online dimana trainer memberikan motivasi harian dengan media sosial (WhatsApp).

Tes pengetahuan pengasuhan. Tes pengetahuan terdiri dari 8 soal. Contoh pertanyaan adalah Apa saja manfaat bermain bagi anak? Dan permainan apa saja yang cocok untuk anak toddler?

Skala Self-Effficacy for Parenting Tasks Index-Toddler Scale (SEPTI-TS) versi pendek (Van Rijen et al., 2014) yang telah diadaptasi oleh Lubis dan Hildayani (2015). Contoh aitem dalam skala tersebut adalah "Sulit bagi saya untuk bermain dan bersantai dengan anak saya" dan "Anak saya merasa sangat dicintai oleh saya" Pengisian jawaban skala menggunakan 6 skala Likert (Sangat Tidak Setuju - Sangat Setuju). Uji coba skala dilakukan oleh peneliti, melibatkan 164 orang. Uji coba dilakukan secara online menggunakan googleform di seluruh Indonesia kecuali Sleman, Kotamadya Yogyakarta dan Bantul yang merupakan wilayah penelitian. SEPTI-TS versi pendek memiliki 26 aitem, namun setelah uji coba, 4 aitem gugur karena memiliki nilai koefisien < 0,30, yaitu aitem 1,2, 5 dan aitem 22. Oleh karena itu skala baru yang digunakan dalam penelitian ini memiliki 22 aitem. Reliabilitas skala baru yang dihitung menggunakan formula Cronbach's Alpha adalah $\alpha=0,862$. Hal ini menunjukkan bahwa skala yang baru memiliki reliabilitas yang baik.

\section{Desain penelitian}

Penelitian ini merupakan penelitian eksperimen kuasi dengan desain untreated control group design with dependent pretest, posttest and follow up. Desain penelitian ini menggunakan kelompok perlakuan dan kelompok pembanding yang tidak diberikan perlakuan (Shadish, Cook \& Campbel, 2002). Penempatan partisipan ke dalam kedua kelompok menggunakan teknik non randomize, partisipan yang bersedia mengikuti pelatihan secara penuh menjadi kelompok eksperimen, sedangkan yang tidak bersedia menjadi kelompok kontrol.

\section{Prosedur penelitian}

Prosedur penelitian yang dilakukan yaitu (1) studi pendahuluan, meliputi observasi di PAUD/TK Alam Avicena, Bantul serta wawancara kepada tiga ibu bekerja dengan anak toddler; (2) persiapan penelitian, meliputi penyusunan program dan modul pelatihan, buku materi dan buku kerja untuk partisipan, pencetakan poster, penyusunan lembar observasi, pembuatan lembar evaluasi pelaksanaan, ujicoba skala, serta pemilihan trainer dan observer; (3) pelaksanaan penelitian, meliputi validasi isi dan validasi fungsional. Validasi isi digunakan untuk memastikan apakah modul yang disusun adalah valid, tidak terbatas pada makna tercapai-tidaknya tujuan pemberian intervensi saja, tetapi mencakup juga makna keselarasan antara isi materi yang diberikan dalam pelatihan dengan tujuannya (Azwar, 2018). Sedangkan validasi fungsional adalah validasi yang ditujukan untuk memastikan bahwa modul intervensi memang berfungsi secara empirik sesuai dengan tujuannya (Azwar, 2018). Validasi fungsional ini meliputi pelaksanaan intervensi, dan 
penghitungan skor skala. Intervensi berupa serangkaian program pelatihan parenting yang terdiri dari 4 sesi offline (2 kali pertemuan dengan jeda 1 pekan), dan 6 hari sesi online dan tugas rumah. Total pelaksanaan intervensi 8 hari.

\section{Pengambilan data}

Pengambilan data dilakukan dengan paper based questionnaire dan Googleform. Follow up dilakukan 2 pekan setelah intervensi. Analisis tambahan dilakukan dengan wawancara terhadap 5 partisipan.

\section{Metode analisis data}

Penelitian ini menggunakan metode kuantitatif, yaitu Mann Whitney U untuk menguji apakah ada perbedaan mean dari gain score (selisih skor dua pengukuran) pada kelompok kontrol dan kelompok eksperimen. Sebagai analisis tambahan dilakukan Wilcoxon Sign Rank Test dan Friedman's Anova untuk menguji perbedaan pretest-posttest-follow up kelompok eksperimen. Analisis data dilakukan menggunakan program SPSS.

Validasi isi dilakukan oleh enam orang ahli yang memberikan penilaian terhadap modul dengan rentang nilai 1 (sangat tidak relevan) - 5 (sangat relevan). Nilai Aiken $\mathrm{V}$ masing-masing kegiatan berada pada rentang nilai 0,667 - 0,958. Sedangkan nilai Aiken V secara keseluruhan yaitu 0,849 . Hal ini menunjukkan bahwa isi modul "Smart Parenting" memiliki validitas isi yang baik $(\mathrm{V}>0,50)$. Para ahli juga memberikan masukan kualitatif seperti penggunaan bahasa, metode, alokasi waktu, ice breaking dan hal-hal teknis terkait proses pelatihan. Modul kemudian direvisi setelah mendapat saran dari para ahli.

Validasi fungsional Modul Pelatihan "Smart Parenting"

Pada histogram kelompok kontrol (Gambar 1) diketahui bahwa NHY, RF, OET, ATN memiliki perbedaan skor yang cukup drastis (> 10 poin). Pada histogram kelompok eksperimen (Gambar 2) LA memiliki skor yang menurun pada saat posttest. Kelima partisipan tersebut kemudian dimasukkan dalam data outlier sehingga tidak diikutkan dalam uji statistic. Uji hipotesis menggunakan uji Mann Whitney dengan langkah-langkah

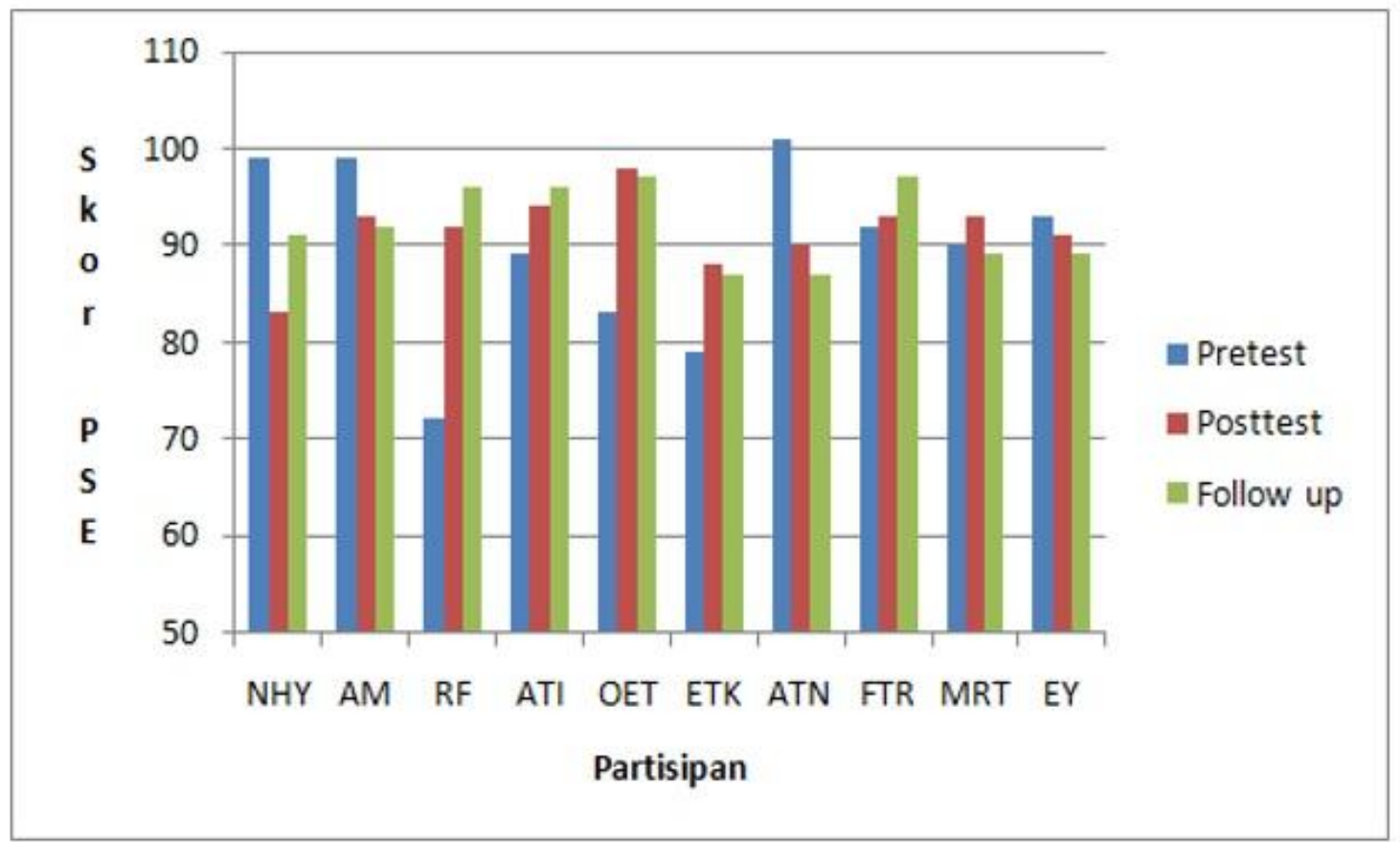

Gambar 1 Histogram skor PSE kelompok kontrol 


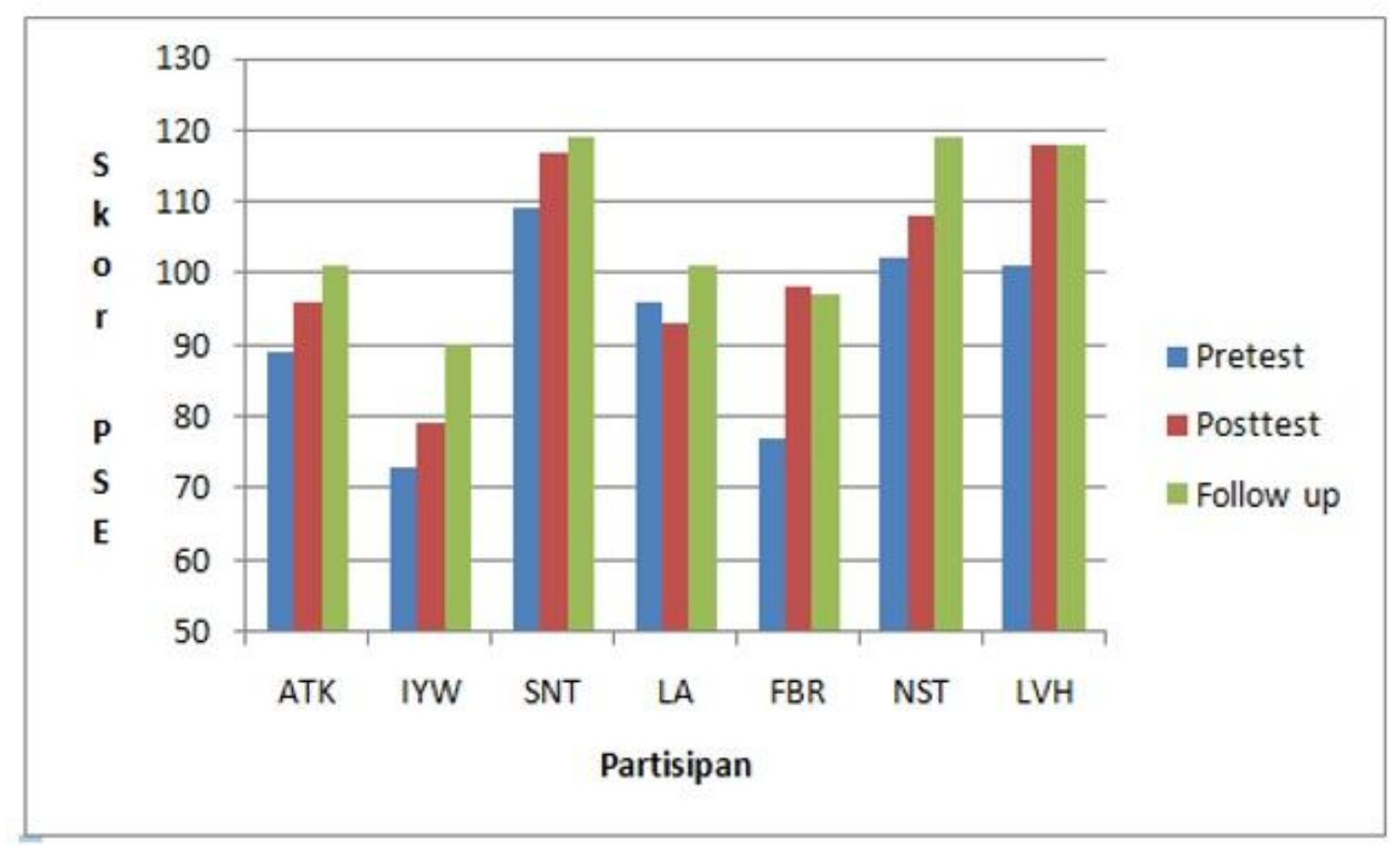

Gambar 2 Histogram skor PSE kelompok eksperimen

pengujian merujuk pada Field (2009). Hasilnya adalah $\mathrm{z}$ sebesar $-2,246$ dan $p$ value sebesar $0,025 \quad(\mathrm{p}<0,05)$. Bisa disimpulkan bahwa ada perbedaan yang signifikan pada skor PSE antara kelompok kontrol dan kelompok eksperimen.

Sebagai analisis tambahan, dilakukan uji Wilcoxon Signed Ranks test. Dari uji tersebut diketahui bahwa nilai $\mathrm{z}$ sebesar 2,207b dengan p-value 0,027 (< $0,05)$. Bisa disimpulkan bahwa terdapat perbedaan yang signifikan antara hasil pretest dan posttest pada kelompok eksperimen. Selain itu juga dilakukan Uji Friedman's Anova, dengan hasil significance value pengujian adalah 0,006 ( $p$ value $<0,05$ ). Bisa disimpulkan bahwa pada pengujian pretests-posttest-follow sekaligus, modul "Smart Parenting" berpengaruh signifikan terhadap peningkatan PSE ibu pada kelompok eksperimen.

Sebagai data tambahan, peneliti melakukan wawancara kepada NST, LA, FBR (kelompok eksperimen) dan RF, ATN dan OET (kelompok kontrol). NST memiliki tren skor yang semakin naik, NST merasa berhasil membentuk sebuah rutinitas yang baik untuk anaknya. LA memiliki skor turun pada periode pretestposttest, LA memiliki banyak idealisme pada saat pertemuan pertama namun gagal dilaksanakan. FBR memiliki kenaikan skor terbanyak, FBR melakukan tugas sesuai prosedur. RF memiliki peningkatan skor tertinggi di kelompok kontrol, RF menerima bonus akhir tahun yang digunakan untuk membayar tunggakan uang sekolah anaknya. OET memiliki peningkatan skor tertinggi setelah RF, OET mengikuti komunitas parenting dan mempratikkan materi yang disampaikan dalam program komunitas parenting tersebut. ATN memiliki tren skor yang semakin menurun di kelompok kontrol. ATN memiliki beban pekerjaan yang meningkat drastis, sehingga mengganggu hubungan dengan suami, anak dan teman sejawat.

\section{Diskusi}

Sejak tahun 2000-an tren pengasuhan memasuki masa transisi dari program 
yang bertujuan untuk memberikan informasi kepada orang tua dan membekalinya dengan keterampilan tertentu, ke program yang bertujuan pada identitas keorangtuaan, pengalaman, keyakinan dan persepsi, kepercayaan diri, dan kecemasan orang tua (Smith dalam Polivanova, Vopilova, \& Nisskaya, 2016). Salah satu konsep yang semakin popular akhir-akhir ini adalah parental self efficacy dan bentuk pengembangan PSE yang tepat adalah melalui training (Polivanova et al., 2016). Penelitian ini bertujuan untuk memvalidasi modul pelatihan "Smart Parenting" dalam meningkatkan parental self efficacy ibu bekerja yang memiliki anak toddler.

Berdasarkan hasil penelitian, modul "Smart Parenting" memiliki validasi isi yang baik. Validasi isi yang baik menunjukkan bahwa modul tersebut telah valid, sesuai dengan tujuan intervensi, dan tercapai keselarasan antara isi materi yang diberikan dalam pelatihan dengan tujuannya (Azwar, 2018) yaitu meningkatkan parental self efficacy. Modul tersebut juga memiliki validasi fungsional yang baik. Partisipan mengalami peningkatan skor PSE yang signifikan setelah mendapat pelatihan.

Selain itu, dari penelitian diketahui bahwa pengetahuan pengasuhan partisipan juga meningkat secara signifikan. Hal ini menunjukkan bahwa bertambahnya pengetahuan pengasuhan seiring dengan meningkatnya PSE. Tomczewski (2009) mengungkapkan bahwa pengetahuan orang tua berhubungan dengan PSE. Hal ini memperkuat pendapat Bandura (1997) yang menjelaskan bahwa pengetahuan merupakan modal bagi individu untuk memberikan penilaian terhadap efikasi dirinya. Spot dan Conroy (dalam Coleman \& Karraker, 1998) juga mengungkapkan bahwa efikasi diri memiliki hubungan positif dengan tendensi spesifik dan perilaku konkret, seperti usaha orang tua untuk mengedukasi dirinya sendiri mengenai pengasuhan, misalnya dengan mengikuti program pendidikan orang tua dan membaca literatur yang relevan dengan pengasuhan.

Salah satu hal yang dinilai efektif mendukung keberhasilan pelatihan ini adalah desain/metode pelatihan. Menurut Burke dan Hutchins (2008) salah satu yang memengaruhi proses transfer dari suatu pelatihan yaitu desain/metode pelatihan. Hal ini selaras dengan pendapat Afiatin, Sonjaya dan Pertiwi (2013) yang menyatakan bahwa salah satu hal yang memengaruhi keberhasilan program pelatihan adalah desain atau transfer pembelajaran meliputi tujuan pembelajaran, relevansi konten, instruksi, metode, media dan strategi pengelolaan diri yang relevan dengan transfer pelatihan.

Pelatihan "Smart Parenting" menggunakan pendekatan experiential learning. Pendekatan ini menekankan pada fase "doing" dan "reflection" dalam tahapan proses belajarnya. Polivanova et al. (2016) mengungkapkan bahwa pengembangan efikasi diri dimungkinkan melalui refleksi, latihan kreatif dan melalui pembuatan strategi pengasuhan anak serta pengambilan keputusan independen dalam konteks lingkungan yang mendukung. Tahap "doing" dan "reflection" ini bisa lebih dijiwai oleh partisipan dengan mengikuti permainan, role-play, diskusi, studi kasus juga presentasi. Tahap selanjutnya adalah "thinking" dan "planning". Pada tahap ini partisipan diajak untuk memikirkan pola pengasuhan yang selama ini dijalankan dan kemudian distimulasi untuk merencanakan perbaikan yang bisa dilakukan. Partisipan diberikan kesempatan untuk memasuki experiential learning cycle yang kedua dengan mempratikkan atau melakukan perbaikan- 
perbaikan yang telah direncanakan selama waktu jeda antara pertemuan pertama dengan pertemuan kedua dan kemudian merefleksikannya dalam buku kerja setiap hari. Pada pertemuan kedua, partisipan akan distimulasi untuk memasuki tahap "thinking" dan "planning" yang kedua kalinya. Secara umum dalam pelatihan ini terdapat dua siklus experiential learning yang dialami oleh partisipan.

Oleh karena itu, hasil penelitian ini menguatkan penelitian-penelitian sebelumnya yang menggunakan metode experiential learning sebagai metode belajar yang efektif untuk meningkatkan self efficacy. Penelitian terdahulu yang menggunakan metode ini antara lain penelitian yang dilakukan oleh Wardhani (2018) untuk meningkatkan parental self efficacy ibu dengan anak usia SD, Zhu (2018) untuk meningkatkan efikasi diri pekerja, Jarpe-Ratner, Folkens, Sharma, Daro, dan Edens (2016) untuk meningkatkan efikasi diri memasak, serta Watters, Stabulas-Savage, Toppin, Janal, dan Robbins (2015) untuk meningkatkan efikasi diri dokter gigi dalam menangani pasien dengan perawatan kesehatan yang khusus.

Dari hasil evaluasi pelatihan, sesi yang paling banyak dipilih sebagai sesi yang paling menarik adalah sesi CeritakuCeritamu (sesi keempat). Sesi ini adalah sesi saat masing-masing partisipan diminta bercerita mengenai kekhawatiran atas ketidakpastian yang dirasakan, bercerita mengenai pengalaman pengasuhan mereka yang berhasil serta pengalaman mereka dalam melakukan tugas rumah khususnya terkait "toples kebaikan". Partisipan yang lain diminta mencari inspirasi apa yang dapat mereka pelajari dari cerita masing-masing partisipan dan menuliskan kalimat apresiasinya dalam sebuah kartu apresiasi yang kemudian diserahkan kepada partisipan yang bercerita tersebut.
Bandura (1989) mengungkapkan bahwa riwayat pencapaian keberhasilan masa lalu memainkan peran yang utama dalam memunculkan efikasi diri. Menurut Alwisol (2009) salah satu cara induksi PSE melalui pengalaman performansi adalah performance exposure, yaitu menonjolkan keberhasilan yang pernah diraih. Hal inilah yang membuat sesi sharing dimungkinkan menjadi sesi yang bisa menguatkan PSE. Dalam sharing tersebut partisipan diminta untuk menceritakan pengalaman pengasuhan yang positif yang selama ini dijalani.

Bandura (1997) juga menyebutkan bahwa sumber efikasi diri yang lain adalah vicarious experience atau pengalaman orang lain. Orang lain yang dimaksud disini adalah orang lain yang dianggap berkedudukan setara. Alwisol (2009) mengemukakan salah satu cara induksi PSE melalui vicarious experience adalah dengan live modeling, yaitu dengan mengamati model yang nyata. Partisipan mengaku bahwa setelah mendengarkan cerita dari masing-masing partisipan, mereka menyadari bahwa ternyata ibu-ibu bekerja yang lain memiliki tantangan yang sama, dan ternyata ibu-ibu yang lain bisa mengatasi tantangan yang timbul dengan cara masing-masing dan bisa berhasil.

Pada sesi ini, partisipan juga diminta untuk menceritakan kekhawatirannya terkait pengasuhan yang dijalankan serta bagaimana mereka mengantisipasinya seperti yang telah dituliskan pada pertemuan pertama. Sharing tentang antisipasi ini bisa menumbuhkan PSE melalui performance exposure dan live modelling. Masing-masing partisipan bisa saling menginspirasi, saling belajar satu sama lain. Baik kekhawatiran maupun langkah-langkah untuk antisipasi yang dirasakan masing-masing partisipan mungkin berbeda satu-sama lain. Dengan sharing partisipan menjadi terbuka wawasannya sehingga memiliki ide untuk 
memperbaiki pengasuhan yang dijalaninya. Beberapa kekhawatiran yang diungkapkan partisipan antara lain anak menjadi lebih dekat dengan orang lain yang mengasuhnya seharian, pengaruh buruk dari lingkungan sekitar, misalnya teman bermain, televisi, dan sebagainya, bullying, dan masalah kesehatan anak. Dari penelitian ini partisipan distimulasi untuk memikirkan antisipasi terhadap munculnya kekhawatiran-kekhawatiran tersebut.

Polivanova et al., (2016) mengungkapkan, bahwa dalam pengasuhan banyak hal yang tidak bisa diprediksikan sebelumnya. Orang tua tidak bisa memprediksikan bahwa pengasuhan yang dijalankan saat ini akan membawa kesuksesan pada sepuluh tahun mendatang atau tidak. Oleh karena itu toleransi terhadap ketidakpastian dan kemampuan untuk bertindak yang tepat dalam situasi yang tidak pasti merupakan hal penting dalam meningkatkan efikasi diri pada orang tua modern (Polivanova et al., 2016). Menurut Schunk (1983) efikasi diri mengacu pada penilaian tentang seberapa baik individu dapat mengatur dan menetapkan tindakan dalam situasi tertentu yang mungkin mengandung unsur-unsur yang ambigu, tidak dapat diprediksi, dan mungkin menimbulkan stress.

Pemberian kartu apresiasi dalam pelatihan ini juga dimungkinkan mampu menumbuhkan PSE melalui verbal persuasion. Alwisol (2009) menyebutkan bahwa salah satu cara induksi PSE melalui verbal persuasion adalah interpretive treatment, yaitu membentuk interpretasi baru untuk memperbaiki interpretasi lama yang salah. Dalam penelitian ini, partisipan mengaku bahwa sebelumnya mereka menganggap praktik pengasuhan yang mereka jalani biasa-biasa saja, namun ternyata bisa menginspirasi orang lain. Penguatan bahwa pengasuhan yang mereka lakukan adalah benar, bahkan bisa menginspirasi orang lain untuk melakukan hal serupa bisa memunculkan interpretasi baru. Hal ini akan menguatkan keyakinan partisipan bahwa mereka mampu mengasuh dengan baik. Suzuki, Holloway, Yamamoto, dan Mindnich (2009) mengungkapkan bahwa ibu yang memiliki PSE tinggi merasakan dukungan yang tinggi pula dari teman-temannya. Temuan dari Borelli et al. (2016) menguatkan hal tersebut, yaitu bahwa ibu yang memiliki PSE tinggi merasakan dukungan dari teman-teman dan suaminya.

Tugas rumah yang diberikan dalam bentuk aktivitas bersama anak juga dimungkinkan mendukung keberhasilan pelatihan ini. Coleman dan Karraker (1998) mengemukakan bahwa salah satu yang berpengaruh dalam menumbuhkan efikasi diri ibu adalah pengalaman nyata antara ibu dan anak. Dewi dan Indrasari (2017) mengemukakan bahwa keterlibatan orang tua dalam pengasuhan (parental involvement) berpengaruh secara signifikan terhadap PSE.

Selain melalui performance exposure, mastery experience juga ditumbuhkan melalui self-instructed performance. Alwisol (2009) menerangkan bahwa self-instructed performance adalah melatih diri untuk melakukan yang terbaik. Hal ini bisa dilihat dari jumlah koin yang terkumpul dalam "toples kebaikan". Dari tugas tersebut, partisipan mengaku bahwa mereka terdorong untuk melakukan suatu kebaikan kepada anak jika di akhir hari belum memasukkan koin ke dalam toples.

Pada saat pelatihan, partisipan dilatih untuk melakukan perbaikan pengasuhan secara terstruktur, Setelah pelatihan berakhir, setiap partisipan diharapkan dapat mengembangkan materi yang didapat dan menyesuaikannya dengan kondisi pengasuhan yang dihadapi masing-masing. Keberhasilan 
dalam kedua kondisi tersebut membawa dampak yang berbeda dalam pengembangan PSE. Feist, Feist, dan Roberts (2017) mengungkapkan bahwa tugas yang diselesaikan oleh diri sendiri lebih efektif meningkatkan efikasi diri daripada dengan bantuan orang lain. Sejalan dengan Feist et al. (2017), temuan dari partisipan NST menyatakan bahwa dirinya merasa senang meskipun sudah tidak ada tugas dari siapapun, namun tetap bisa membentuk rutinitas anak setelah pelatihan berakhir. Hal ini menguatkan pendapat Dowling (2014) dan Buchanan dan Glazt (2015) bahwa praktik pengasuhan yang ibu jalankan berhubungan dengan parental self-efficacy.

Sumber efikasi lain yang dikembangkan dalam pelatihan ini adalah psychological and affective states. Penghitungan koin kebaikan, pemberian kartu apresiasi dan pemberian sertifikat bisa meningkatkan penghargaan partisipan terhadap dirinya sendiri. Salah satu partisipan mengaku bahwa baru sekali ini dirinya merasa dihargai sebagai ibu karena diberikan sertifikat "Best Mom Award".

Faktor lain yang dimungkinkan turut menyumbang keberhasilan pelatihan ini adalah karakteristik trainer. Burker dan Hutchins (2008) menjelaskan bahwa karakteristik trainer meliputi kecakapan atau pengetahuan terhadap materi pelatihan, pengalaman profesional, serta pengetahuan terhadap prinsip pengetahuan. Trainer yang membawakan modul dalam penelitian ini adalah seorang psikolog anak, sehingga dinilai dari kecakapan profesionalitasnya bisa terpenuhi. Trainer bisa menumbuhkan PSE partisipan melalui verbal persuasion dengan cara suggestion dan exhortation. Menurut Alwisol (2009) suggestion adalah proses memengaruhi dengan kata-kata berdasar kepercayaan, sedangkan exhortation adalah nasihat ataupun peringatan yang mendesak/memaksa. Dalam hal ini, trainer dimungkinkan dipercaya oleh partisipan karena pengalaman akademis, pengalaman pekerjaannya maupun pengalaman praktik pengasuhan karena trainer juga memiliki anak usia toddler seperti halnya partisipan.

Faktor eksternal lain yang mungkin berpengaruh adalah lingkungan kerja. Burke dan Hutchins (2008) mengungkapkan bahwa faktor lingkungan kerja dapat memengaruhi proses transfer dalam pelatihan. Faktor lingkungan kerja ini meliputi hal-hal yang bisa memengaruhi transfer pelatihan diluar pelatihan itu sendiri. Selama pelatihan, peneliti memfasilitasi dengan menyediakan kids zone bagi ibu yang membawa anak supaya partisipan bisa berkonsentrasi penuh terhadap materi pelatihan. Area yang digunakan untuk kids zone berada di ruangan yang terpisah dengan ruang utama pelatihan, namun masih bisa terakses dengan mudah karena ruangannya saling berhadap-hadapan. Partisipan LA mengaku bahwa pelatihan "Smart Parenting" merupakan pelatihan paling ramah anak.

Berdasarkan hasil penelitian juga diketahui bahwa beberapa partisipan dalam kelompok kontrol memiliki kenaikan/penurunan skor PSE yang cukup besar. Padahal, kelompok kontrol adalah kelompok pembanding yang tidak diberi perlakuan sehingga diprediksikan tidak akan mengalami perubahan yang berarti pada skor variabel dependennya setelah eksperimen selesai (Azwar, 2016). Oleh karena itu peneliti melakukan wawancara terhadap ATN, OET dan RF. Dari wawancara diketahui bahwa dimungkinkan ada faktor lain yang memengaruhi PSE yaitu pendapatan, dukungan informasional dan dukungan sosial dari orang terdekat. Hal ini menguatkan beberapa penelitian 
sebelumnya. Colemann dan Karraker (2000) serta Yu (2011) mengungkapkan bahwa semakin tinggi pendapatan maka semakin tinggi pula PSE. Yu (2011) juga mengungkapkan bahwa dukungan sosial termasuk faktor yang memengaruhi PSE. Dukungan sosial ini bisa bersumber dari pasangan, orang tua, maupun komunitas. Temuan Young (2012), Gao, Sun, dan Chan (2014) mengungkapkan hal yang sama. Menurut Sevigny dan Loutzenhiser (2009) fungsi relational seperti kepuasan pernikahan dan fungsi keluarga memprediksi PSE ibu. Khusus padad kasus ATN, hubungan yang tidak baik dengan orang lain membuat stress meningkat. Bloomfield dan Kendall (2012) menyatakan bahwa ibu yang memiliki PSE yang rendah memiliki tingkat stres yang tinggi dan sebaliknya. Alwisol (2009) mengungkapkan bahwa emosi yang kuat dan stres dapat menurunkan efikasi diri.

Salah satu keterbatasan dalam penelitian adalah jumlah sampel yang terlalu sedikit. Sedikitnya jumlah partisipan menyebabkan metode analisis data menggunakan analisis nonparametrik, sehingga memiliki kelemahan dalam power efficiency. Keterbatasan dalam penelitian ini juga terletak pada tidak adanya prosedur uji coba modul. Oleh karena itu trainer tidak berkesempatan untuk memperagakan modul dalam bentuk role play.

\section{Kesimpulan}

Berdasarkan hasil penelitian, dapat ditarik kesimpulan bahwa pelatihan "Smart Parenting" berpengaruh secara signifikan dalam meningkatkan PSE ibu bekerja dengan anak toddler. Dari penelitian tersebut juga diketahui bahwa PSE bersifat fluktuatif dan dipengaruhi oleh banyak faktor, antara lain faktor pendapatan, dukungan informasional dan dukungan sosial dari orang terdekat.
Saran

Penelitian ini dapat menjadi alternatif program pengasuhan yang selama ini banyak menekankan pada keterampilan pengasuhan. Selain itu, peneliti selanjutnya bisa lebih menggali faktorfaktor apa saja yang secara khusus banyak memengaruhi PSE ibu yang bekerja yang memiliki anak usia toddler. Terkait dengan intolerance of uncertainty, peneliti selanjutnya bisa menggali lebih lanjut mengenai hubungan antara intolerance of uncertainty dengan PSE. Selain itu, Modul "Smart Parenting" juga masih perlu diuji cobakan pada partisipan dengan tingkat pendidikan SMA atau yang lebih rendah dalam jumlah partisipan yang lebih banyak.

\section{Daftar Pustaka}

Afiatin, T., Sonjaya, J. A., \& Pertiwi, Y. G. (2013). Mudah dan sukses menyelenggarakan pelatihan: Melejitkan potensi diri. Yogyakarta: Kanisius.

Alwisol. (2009). Psikologi kepribadian (Edisi revisi). Malang: UMM Press.

Azwar, S. (2016). Reliabilitas dan validitas skala (Edisi keempat). Yogyakarta: Pustaka Pelajar

Azwar, S. (2018). Metode penelitian psikologi (Edisi kedua). Yogyakarta: Pustaka Pelajar

Bandura, A. (1989). Social cognitive theory. In R. Vasta (Ed.), Annals of child development. Vol. 6 . Six theories of child development (pp. 1-60). Greenwich, CT: JAI Press.

Bandura, A. (1997). Self-efficacy the exercise of control. New York: W. H. Freeman and Company.

Bloomfield, L \& Kendall, S. (2012). Parenting self-efficacy, parenting stress and child behaviour before and after a parenting programme. Primary Health Care Research $\mathcal{E}$ 
Development, 13(4), 364-372. doi: $10.1017 /$ S1463423612000060

Borelli, J. L., Nelson, S. K., River, L. M., Birken, S. A., Moss-Racusin, C. (2016). Gender differences in workfamily guilt in parents of young children. Sex Roles, 76(5-6), 356-368. doi: 10.1007/s11199-016-0579-0

Buchanan, C. M. \& Glazt, T. (2015). Overtime association among parental selfefficacy, promoting parenting practices, and adolescent externalizing behaviors. Journal of Family Psychology, 29(3), 427-437. doi: $\underline{10.1037 / \text { fam } 0000076}$

Burke, L. A \& Hutchins, H. M. (2008). A study of best practices in training transfer and proposed model of transfer. Human Resource Development Quarterly, 19, 107-128. doi: 10.1002.hrdq. 1230

Coleman, P. K., \& Karraker, K. H. (1998). Self-efficacy and parenting quality: findings and future applications. Developmental Review, 18(1), 47-85. doi: $\underline{10.1006 / \text { drev.1997.0448 }}$

Coleman, P. K., \& Karraker, K. H. (2000). Parenting self-efficacy among mothers of school-age children: Conceptualization, measurement, and correlates. Family Relations, 49(1), 13-24. doi: 10.1111/j.17413729.2000.00013.x

Coleman, P. K., \& Karraker, K. H. (2003). Maternal self-efficacy beliefs, competence in parenting, and toddlers' behavior and developmental status. Infant Mental Health Journal, 24(2), 126-148. doi: 10.1002/imhj.10048

Crouter, A. C., \& McHale, S. M. (2005). The long arm of the job revisited: Parenting in dual-earner families. In T. Luster \& L. Okagaki (Eds.), Monographs in parenting. Parenting: An ecological perspective (pp. 275-296). Mahwah,
NJ, US: Lawrence Erlbaum Associates Publishers.

Dewi, M., \& Indrasari, S. Y. (2017). The influence of parental involvement on parenting self efficacy among parents with middle childhood children. Proceeding Conference Faculty of Psychology Universitas Indonesia, Depok.

Dowling, H. (2014). Parental self-efficacy in early years parenting (Disertasi doktoral tidak dipublikasikan). School of Psychological Science University of Manchester, USA

Feist, J., Feist, G. J. \& Roberts, A. (2017). Teori kepribadian (Edisi kedelapan). Terjemahan oleh R. A. Hadwitia Dewi Pertiwi. Jakarta: Salemaba Humanika

Field, A. (2009). Discovering statistic using SPSS (Edisi ketiga). Dubai: Sage Publication Ltd.

Gao, L., Sun, K., \& Chan, S. W. (2014). Social support and parenting selfefficacy among Chinese women in the perinatal period. Midwifery, 30(5), 532-538.

doi: 10.1016/j.midw.2013.06.007

Greenhaus, J. H., Collins, K. M., \& Shaw, J. D. (2003). The relation between work-family balance and quality of life. Journal of Vocational Behavior, 63(3), 510-531. doi: 10.1016/S00018791(02)00042-8

Grzywacz, J. G., \& Carlson, D. S. (2007). Conceptualizing work - family balance: Implications for practice and research. Advances in Developing Human Resources, 9(4), 455-471. doi: $\underline{10.1177 / 1523422307305487}$

Holden, G. W. (2015). Parenting: A dynamic perspective. USA: SAGE Publication

Huilan, X., Wen, L. M., \& Chris, L. (2015). Association of parental influences with physical activity and screen time among young children: A 
systematic review. Journal of Obesity. doi: $10.1155 / 2015 / 546925$

Izzo, C., Weiss, L., Shanahan, T., \& Rodriguez-Brown, F. (2000). Parental self-efficacy and social support as predictors of parenting practices and children's socioemotional adjustment in Mexican immigrant Families. Journal of Prevention $\mathcal{E}$ Intervention in the Community, 20(12), 197-213. doi: $\underline{10.1300 /}$ J005v20n01 13

Jarpe-Ratner, E., Folkens, S., Sharma, S., Daro, D., \& Edens, N. K. (2016). An experiential cooking and utrnition education program increases cooking s elf- efficacy and vegetable consumption in children in grades 38. Journal of Nutrition Education and Behavior, 48(10), 697-705. doi: 10.1016/j.jneb.2016.07.021

Jones, T. L., \& Prinz, R. J. (2005). Potential roles of parental self-efficacy in parent and child adjustment: A review. Clinical Psychology Review, 25(3), 341-363. doi: 10.1016/ j.cpr.2004.12.004

Kolb, D. A. (2015). Experiential learning: experience as the source of learning and development (Second edition). Upper Saddle River, New Jersey: Pearson Education, Inc.

Khotimah, K. (2009). Diskriminasi gender terhadap perempuan dalam sektor pekerjaan. Yin Yang: Jurnal Studi Gender dan Anak, 4(1), 158-180. doi: 10.24090/YY.V4I1.2009.PP158-180

Levine, L. E., \& Munsch, J. (2011). Child development: An active learning approach. Canada: SAGE Publication.

Lubis, N. Y., \& Hildayani, R. (2015). Hubungan antara parenting self efficacy dan interaksi ibu-anak toddler pada ibu dari keluarga miskin (Skripsi tidak dipublikasikan). Fakultas Psikologi Universitas Indonesia, Depok
Nafisah, D. (2008). Politisasi relasi suamiistri: Telaah KHI perspektif gender. Yin Yang: Jurnal Studi Gender dan Anak, 3(2), 195-208. doi: 10.24090/ YY.V3I2.2008.PP195-208

Ningrum, A. K. (2016). Parenting self efficacy pada ibu bekerja dengan anak usia pra sekolah (Skripsi tidak dipublikasikan). Fakultas Psikologi Universitas Islam Negeri Syarif Hidayatullah, Jakarta.

Polivanova, K., Vopilova, I., \& Nisskaya, A. (2016). Parenting education history and modern trends: Self-efficacy as a methodological base for the development of educational programs for parents. Working paper. National Research University Higher School of Economic (HSE) Moscow

Rachmawati, A. N., \& Hastuti, D. (2017). Parental self-efficacy dan praktik pengasuhan menentukan perilaku agresif anak usia pra sekolah. Jurnal Ilmu Keluarga dan Konsumen, 10(3), 227-237. doi: 10.24156/jikk.2017. $\underline{10.3 .227}$

Roqib, M. (2007). Harmoni dalam budaya jawa (Dimensi edukasi dan keadilan gender). Purwokerto: STAIN Purwokerto Press.

Sansom, L. (2010). Confident parenting - A book proposal. Master of Applied Positive Psychology (MAPP) Capstone Projects .1525.

Schunk, D. H. (1983). Ability versus effort attributional feedback: Differential effects on self-efficacy and achievement. Journal of Educational Psychology, 75, 848-856. doi: $\underline{10.1037 / 0022-0663.75 .6 .848}$

Sevigny, P. R., \& Loutzenhiser, L. (2009). Predictors of parenting self-efficacy in mothers and fathers of toddlers. Child: Care, Health and Development, 36(2), 179-189. doi: 10.1111/j.13652214.2009.00980.x 
Shadish, Cook, \& Campbell. (2002). Experimental and quasi-experimental designs for generalized causal inference. USA: Houghton Mifflin Company.

Smith, E. (2017). The role of parental selfefficacy, hardiness, parenting stress in predicting parenting behaviors (Disertasi doktoral tidak dipublikasikan). The Aquila Digital Community, University of Southern Mississipi, USA.

Suzuki, S., Holloway, S. D., Yamamoto, Y., Mindnich, J. D. (2009). Parenting selfefficacy dan social support in Japan and United Stated. Journal of Family Issues, 30(11), 1505-1526

Tomczewski, D. K. (2009). Predictors of anticipated parenting efficacy in younger adults (Tesis master tidak dipublikasikan). Department of Psychology West Virginia University, Morgantown

Van Rijen, E. H. M., Gasanova, N., Boonstra, A. M., \& Huijding, J. (2014). Psychometric qualities of the short form of the self-efficacy for Parenting Tasks Index-Toddler Scale. Child Psychiatry \& Human Development, 45(4), 443-455. doi: 10.1007/s10578$\underline{013-0414-6}$

Wardhani, Y. A. (2018). Validasi modul pelatihan penasuhan mandiri untuk meningkatkan efikasi diri ibu bekerja dalam mengasuh anak usia sekolah. (Tesis master tidak dipublikasikan). Magister Profesi Psikologi, Universitas Gadjah Mada, Yogyakarta
Watters, A. L., Stabulas-Savage, J., Toppin, J. D., Janal, M. N., \& Robbins, M. R. (2015). Incorporating experiential learning techniques to improve selfefficacy in clinical special care dentistry education. Journal of Dental Education, 79(9), 1016-1023

Wepfer, A. G., Brauchli, R., Jenny, G. J., Hämmig, O., \& Bauer, G. F. (2015). The experience of work-life balance across family-life stages in Switzerland: A cross-sectional questionnaire-based study. BMC Public Health, 15(1). doi: 10.1186/s12889-015- 2584-6

Wittkowski, A., Garrett, C., Calam, R., \& Weisberg, D. (2017). Self-report measures of parental self-efficacy: A systematic review of the current literature. Journal of Child and Family Studies, 26(11), 2960-2978. doi: 10.1007/s10826-017-0830-5

Young, S. L. (2012). Exploring the relationship between parental selfefficacy and social support system. Theses. IOWA State University.

Yu, M. (2011). Parenting efficacy: How can service provider help? Family Relationship Quaterly, 19. Diunduh dari https://aifs.gov.au/cfca/ publications/family-relationshipsquarterly-no-19/parenting- efficacyhow-can-service-providers-help (diakses pada 3 November 2018)

Zhu, Z. M. (2018). Effects of the practice of experiential education on employee self-efficacy and organizational commitment in catering industry. Journal Math, Science, Technology, 14(3), 745-751. doi: $\underline{10.12973 / \text { ejmste/80 }}$ 